\title{
Legal Review Enforcement Repressive Legal Efforts Against Narcotics Users Of Children
}

\author{
Alfredo Risano ${ }^{1}$, Ayu Dian Ningtias ${ }^{2}$ \\ alfredorisano@gmail.com, ayudianningtias99@gmail.com \\ ${ }^{1}$ Faculty of Law, Universitas Airlangga Surabaya \\ ${ }^{2}$ Faculty of Law, Universitas Islam Lamongan
}

\begin{abstract}
In terms of enforcement the law. Second, legal instruments in the framework of criminal law enforcement abuse of narcotics against minors using a legal basis Law Number 11 of 2012 concerning the Criminal Justice System for Children. In the the provisions of the SPPA Law, in order to prosecute children who are involved with the law, then a diversion effort is carried out, namely a restorative effort or recovery state solve the problem together, in this research is focous about How are repressive legal measures against child narcotics users in under age? As previously explained, in act Number 11 In 2012 concerning the Juvenile Criminal Justice System, there is a restorative principle (Restorative justice), which is aimed at restoring the original state, meaning efforts to restore the attitudes and mentality of children who have committed acts the crime of narcotics abuse to be as before or as a cure for the criminal act he has committed. Of course, the provisions of the Narcotics Law are not sidelined even though his repressive legal remedies are based on the provisions of law SPPA.
\end{abstract}

\section{Keywords: Repressive Legal Efforts, Child Narcotics Users,Criminal Law Enforcement.}

\section{Introduction}

The importance of family education is addressed to the child, by weighing it polemic that occurs against the free association of children, then it needs to be pursued for parents in order to educate children properly. So that children can be avoided the scope of promiscuity, especially the rampant cases of illegal narcotics trafficking rarely involves a minor. There are two sides to dealing with the case abuse of narcotics by minors. On the one hand, the position of the child as narcotics abuse is possible as a 'victim' of narcotics abuse, on the other hand, the child's position as narcotics abuse can be assessed as 'Suspect / perpetrator' as threatened by Article 127 paragraph (1) letter a of the Law Narcotics. In essence, drug users are victims who make mistakes and not a criminal. If viewed more deeply, in the practice of narcotics trafficking, then the position of narcotics users is in the position of consumers. While dealers narcotics and dealers, namely parties that provide all types of narcotics. There are two the 
problem is repressive legal measures against child narcotics users age and legal instruments used in enforcing criminal law against child narcotics users. This writing uses the juridical method normative approach to legislation and concepts. ${ }^{1}$

From the research results it can be concluded that repressive legal measures against users narcotics for minors, namely mandatory rehabilitation efforts and parents shall be obliged to report to the medical party as stipulated in Article 55 paragraph (1) of the Law. Law Number 35 of 2009 concerning Narcotics. Rehabilitation efforts need to be carried out, remembering children as the younger generation who in turn will continue as well realizing the ideals of the nation. Besides, treatment efforts must be made through rehabilitation. In line with that, it also protects children's rights to grow and develop as confirmed in international legal instruments as well national. Meanwhile, legal instruments are used in enforcing criminal law against child narcotics users. ${ }^{2}$ First, legal instruments based on Law Number 35 of 2009 concerning Narcotics. UU Narcotics does not explicitly regulate the imposition of sanctions against children in minors involved in narcotics abuse. ${ }^{3}$ In terms of enforcement the law. Second, legal instruments in the framework of criminal law enforcement abuse of narcotics against minors using a legal basis Law Number 11 of 2012 concerning the Criminal Justice System for Children. In the the provisions of the SPPA Law, in order to prosecute children who are involved with the law, then a diversion effort is carried out, namely a restorative effort or recovery state solve the problem together, in this research is focous about How are repressive legal measures against child narcotics users in under age?

\section{Sub Title}

In order to enforce the law, especially in criminal law enforcement, in it there is an attempt or effort made by law enforcement officials in enforcing criminal law against criminal acts committed by someone. Repressive legal measures are part of a series of enforcement criminal law, this repressive effort is carried out by law enforcement officials at any time an act or criminal act is committed by someone who in this case has committed and cause the consequences of a criminal act. In essence, repressive legal measures are also part

\footnotetext{
${ }^{1}$ Setiono, Rule of Law (Supremasi Hukum), Magister Ilmu Hukum Pasca Sarjana Universitas Sebelas maret, Surakarta, 2004, page. 3

${ }^{2}$ Phillipus M. Hadjon, Perlindungan Hukum Bagi Rakyat Indonesia, PT. Bina Ilmu, 1987, page. 2.

3 Muchsin, Perlindungan dan Kepastian Hukum Bagi Investor di Indonesia, Magister Ilmu Hukum Program Pascasarjana Universitas Sebelas Maret, Surakarta, 2003, page. 20.
} 
of legal protection. Regarding legal protection, explained by Setiono in his writings, namely as follows;

Legal protection is an act or effort to protect society from arbitrary actions by the authorities that are not in accordance with the rule of law, to create order and tranquility, so that enable humans to enjoy their dignity as human beings. From the explanation above, legal protection is an effort to protect the community from arbitrariness by law enforcement officials, this is applies especially to someone who has committed a criminal act.

Regarding repressive legal measures, as included in the form legal protection, it is necessary to explain the meaning of protection repressive laws as described in the book of Phillipus M. Hadjon, as the following: ${ }^{4}$

Repressive Legal Protection Means. Repressive legal protection aims to resolve disputes. Handling legal protection by General Courts and Administrative Courts in Indonesia incl this category of legal protection. The second principle underlying protection law against governmental acts is the principle of a rule of law. Linked with recognition and protection of human rights, recognition and protection of human rights has a place primary and can be linked to the objectives of the rule of law.

Repressive legal measures or repressive legal protection are efforts which aims to resolve disputes, the intended form of protection namely on human rights. In addition, it is still about legal protection repressive, explained by Muchsin in his writing, which is as follows: Repressive Legal Protection. Repressive legal protection is final protection in the form of sanctions such as fines, imprisonment and punishment additional given when a dispute has occurred or has been carried out an offense.

In the discussion above, we discussed legal protection measures and repressive legal remedies in the framework of broadly enforcing criminal law, at This discussion will discuss the legal implications of its application repressive legal remedies against child narcotics abuse. Broadly speaking, repressive legal measures in the context of criminal law enforcement indeed, it is essentially the same, namely enforcing the rule of law the moment after the occurrence of a criminal act, in the form of arrest, investigation, investigation up to prosecution. However, on repressive legal measures in the context of enforcement the law,

\footnotetext{
${ }^{4}$ Luthvy Febrika Nola, Upaya Perlindungan Hukum Secara Terpadu, Negara Hukum, Vol. 7, No. 1 Juni 2016, page. 40 .
} 
will be narrowly different, especially in terms of legal implications against the perpetrator of a criminal act.

If we look at the impact if it is consumed by the human body, what more consumed by minors, the types and impacts can be seen through Elucidation of Law Number 35 of 2009 concerning Narcotics. In section General Elucidation of Law Number 35 of 2009 concerning Narcotics ${ }^{5}$, states that Narcotics is a substance or drug that is very useful and necessary for the treatment of certain diseases. However, if it is abused or used not in accordance with standard treatment can have severe consequences very detrimental to individuals or society, especially the younger generation. Thing this will be more detrimental if accompanied by abuse and illicit trafficking Narcotics which can lead to greater harm to life and the cultural values of the nation which will ultimately weaken resilience national.

\section{Conclusion}

Repressive legal action against minors involved Narcotics crime, if it is based on the provisions of Act Number 112012 concerning the Juvenile Criminal Justice System, the provisions can be applied diversion related to its repressive legal measures. As previously explained, in act Number 11 In 2012 concerning the Juvenile Criminal Justice System, there is a restorative principle (Restorative justice), which is aimed at restoring the original state, meaning efforts to restore the attitudes and mentality of children who have committed acts the crime of narcotics abuse to be as before or as a cure for the criminal act he has committed. Of course, the provisions of the Narcotics Law are not sidelined even though his repressive legal remedies are based on the provisions of law SPPA. The provisions of the Narcotics Law can be enforced to impose sanctions rehabilitation of children, especially children who experience dependence on narcotics. As for the provisions regarding diversion against minors who are involved in the crime of narcotics abuse, will be discussed in the chapter The next one that discusses law enforcement instruments against children in minors involved in the crime of narcotics abuse.

\section{Bibliography}

\section{Books}

Luthvy Febrika Nola, Upaya Perlindungan Hukum Secara Terpadu, Negara Hukum, Vol. 7 , No. 1 Juni 2016.

\footnotetext{
${ }^{5}$ Explanation Of act Number 35 Of 2009 about Concerning Narcotics.
} 
Muchsin, Perlindungan dan Kepastian Hukum Bagi Investor di Indonesia, Magister Ilmu Hukum Program Pascasarjana Universitas Sebelas Maret, Surakarta, 2003.

Phillipus M. Hadjon, Perlindungan Hukum Bagi Rakyat Indonesia, PT. Bina Ilmu, 1987.

Setiono, Rule of Law (Supremasi Hukum), Magister Ilmu Hukum Pasca Sarjana Universitas Sebelas maret, Surakarta, 2004.

Act

Undang-Undang Dasar Negara Republik Indonesia Tahun 1945

Undang-Undang Nomor 8 Tahun 1981 Tentang Kitab Undang-Undang Hukum Acara Pidana

Undang-Undang Nomor 35 Tahun 2009 Tentang Narkotika Bagian Umum

Undang Nomor 11 Tahun 2012 Tentang Sistem Peradilan Pidana Anak (SPPA)

Undang-Undang Nomor 35 Tahun 2014 Tentang Perlindungan Anak

Peraturan Presiden Nomor 23 Tahun 2010 Tentang Badan Narkotika Nasional

Konvensi Hak-Hak Anak (Convention on the Rights of the Child) 